\title{
Developmental and chemical characteristics of Melittis melissophyllum L. in limited access of sunlight
}

\author{
IZABELA SZYMBORSKA-SANDHU
}

Department of Vegetable and Medicinal Plants

Institute of Horticultural Sciences

Warsaw University of Life Sciences-SGGW

Nowoursynowska 166

02-787 Warsaw, Poland

*adress for correspondence: izabela_szymborska@sggw.edu.pl

\section{Summary}

Introduction: Bastard balm grows in forests, in central and southeastern part of Europe. The herb of this species is rich in phenolics, mainly flavonoids, phenolic acids and coumarins. The plant is used in traditional European medicine, in digestive problems and for aromatizing tobacco and alcohol products.

Objective: The purpose of this study was to determine the influence of shading on bastard balm development and the accumulation of phenolics in its herb, with special respect to coumarin as a quality marker of this raw material.

Methods: The plants were cultivated in full sunlight, in $30 \%$ and $50 \%$ shade provided by shading nets. The herb was harvested from plants in the third year of vegetation, at four subsequent developmental stages and then subjected to chemical evaluation. In the raw material, the total contents of flavonoids, phenolic acids and coumarins was determined. The content of coumarin was analyzed using HPLC-DAD.

Results: Plants grown in 30\% shade produced the highest number of flowers and seeds. They produced the highest mass of herb at the beginning of the seed-setting stage. The plants grown in full sunlight revealed the highest content of flavonoids and phenolic acids, especially during flowering and at the beginning of the seed-setting stage. The mass of herb obtained by plants cultivated at deep (50\%) shade was the lowest, however, the content of coumarin in these plants was the highest.

Conclusion: The influence of shade on bastard balm was expressed by the herb mass and coumarin content increment. The plants thrived best in $30 \%$ shade, both in terms of flowering abundance and the mass of herb, whereas those from $50 \%$ shade were the richest in coumarin.

Key words: shading, developmental stage, seed viability, flavonoids, phenolic acids, coumarins

Słowa kluczowe: zacienienie, fazy rozwojowe, żywotność nasion, flawonoidy, kwasy fenolowe, kumaryny 


\section{INTRODUCTION}

Bastard balm (Melittis melissophyllum L., Lamiaceae) is a wild-growing plant, occurring mainly in bright oak or mixed forests on the area of Southern and Central Europe. The species prefers semi-shaded sites. It grows in small, scattered populations, located usually far from each other and characterized by a relatively small number of individuals. The plant begins vegetation in the second half of April, when the trees under which it grows, do not shade the forest undergrowth. This rhizomatous perennial plant, with several single stems, grows up to $80 \mathrm{~cm}$. Its leaves are short-petioled, from oval to elliptic lanceolate, 7-15 cm long with notched-serrated margin. White-pink flowers are gathered in the leaf axils at the top of the shoots. The fruit is a fourfold schizocarp [1]. The raw material collected from this species is a herb (upper, not wooden parts of shoots, with leaves and flowers), rich in coumarins (with coumarin as a dominant compound), flavonoids (apigenin, luteolin and kaempferol), triterpenes, phenolic acids (rosmarinic, caffeic and chlorogenic acids), sterols, and iridoids (harpagide, ajugol, melitoside, monomelittoside) [2-4]. Its leaves contain about $0.09 \%$ of essential oil with more than 100 compounds identified so far. Among these, the dominants are 1-octen-3-ol, n-hexadecanoic acid, phytol, ledol, $\alpha$-pinene, coumarin, sabinene, germacrene $\mathrm{D}[5,6]$. One of the most important compounds in the essential oil is 1-octen-3-ol, responsible for specific mushroom-like odour, potentially desirable in food industry [7]. Due to its aroma, this herb is used for the production of extract aromatizing alcohol products [8]. In traditional medicine, bastard balm is used as antispasmodic agent, in insomnia and eye inflammation. In Italy, the decoction is used as a digestive agent or in the treatment of cough and sore throat [9]; while in Serbia, due to its sedative properties, it is used against anxiety and hysteria [10].

The information on bastard balm development and chemical traits is relatively scarce and concerns mainly the composition of phenolic compounds and essential oil in plants growing wild. Some data on its reintroduction into natural sites are also available. It has been observed that the species grows better in shade conditions, as compared to direct sunlight. In situ, it begins generative development only in the third year of vegetation. In the subsequent years, the plant blooms annually, increasing the number of flowering shoots and the number of flowers [11, 12]. Bastard balm is a typical forest species. The disappearance of the species on natural sites may be related with excessive shading of the forests' groundcover due to the intensive development of deciduous trees and brushes. This phenomenon has previously been observed for other undergrowth species, such as Hierochloë australis or Cimicifuga europaea [13]. The shade level is considered to be one of the most important factors promoting the development of these plants. Thus, the purpose of the research was to assess, in cultivation conditions, the effects of shading level on the development of bastard balm and the accumulation of secondary metabolites in its herb, with particular emphasis to the content of coumarin as a quality marker of this raw material.

\section{MATERIALS AND METHODS}

\section{Field experiment}

The field experiment was established at the experimental station of the Department of Vegetable and Medicinal Plants, Warsaw University of Life Science (WULSSGGW), Wilanów, on a medium-heavy alluvial soil. In the early spring of 2017, the soil was fertilized and loosen using composted manure $\left(30 \mathrm{tha}^{-1}\right)$ and tree bark.

The object of the study were seedlings of bastard balm obtained by in vitro techniques. The origin of maternal plants and the production of seedlings was described earlier by Bączek et al. [14]. The plants were planted out in May, 2017. Three variants of shade level, i.e. $0 \%$ (full sunlight), 30\% (moderate shade) and 50\% (deep shade), were obtained using shading nets. At each variant, seedlings were planted out in four replication plots (20 plants per one plot), with spacing of $50 \times 40 \mathrm{~cm}$.

The measurements of developmental traits and the harvest of raw material were performed on threeyear-old plants, in 2019. The meteorological data of this period are provided in table 1 [15], whereas the intensity of photosynthetic active irradiation (phytophotometer RF-100, Sonopan) was measured two times in the season, i.e. at the full-flowering stage and at the end of vegetation (tab. 2).

The herb was cut four times during growing season. The first harvest was performed at the beginning of vegetation (mid-May), second - during the full flowering (mid-June), third - at the seed-setting stage (end of June), and fourth - at the end of plants vegetation (August). Plants were cut at a height of 5-10 $\mathrm{cm}$ above the ground level, higher than first internode. Fresh (FW) and dry weight (DW) of herb 
Table 1

Monthly temperature and precipitation during growing season

\begin{tabular}{lllllllllllll}
\hline Parameters & Jan & Feb & Mar & Apr & May & Jun & Jul & Aug & Sept & Oct & Nov & Dec \\
\hline Temperature $\left[{ }^{\circ} \mathrm{C}\right]$ & -2 & -4 & 8 & 13 & 16 & 26 & 21 & 24 & 17 & 14 & 8 & 4 \\
\hline Precipitation $[\mathrm{mm}]$ & 62.4 & 31.2 & 53.8 & 17.08 & 143.4 & 39.3 & 54.9 & 71.9 & 78.4 & 39.3 & 20.8 & 43.1 \\
\hline
\end{tabular}

Table 2

The intensity of photosynthetic active irradiation at different shade level (PAR; $\mu \mathrm{mol}$ photons $\mathrm{m}^{-2} \mathrm{~s}^{-1}$ )

\begin{tabular}{llll}
\hline \multirow{2}{*}{ Developmental stage of plants } & \multicolumn{3}{c}{ Shade level } \\
\cline { 2 - 4 } & $0 \%$ & $30 \%$ & $50 \%$ \\
\hline Full flowering stage (mid-June) & 2650 & 1950 & 830 \\
\hline End of vegetation (end of August) & 2400 & 1740 & 740 \\
\hline
\end{tabular}

was calculated in g per plant, for each plant separately. The raw material was dried in the dark, in $35^{\circ} \mathrm{C}$, than powdered and subjected to chemical analysis. For the analysis, bulk samples were prepared.

Before each harvest, the plants were assessed in morphological traits such as the number of shoots per plant and their length. At the full flowering stage, the number of flowers per shoot was assessed. Directly after ripening, the seeds were collected, and the number of schizocarps and mericarps per shoot were also calculated. The observations were performed on five plants, in three replications and the data were presented as mean values.

\section{Seed parameters}

The investigated parameters, i.e. 1000-seed mass and their viability were determined according to the method of the International Seed Testing Association [16]. Viability was assessed only for the seed material obtained from the plants grown in full sunlight and those grown in $30 \%$ shade, as there were found not enough well-developed seeds in plants grown in $50 \%$ shade to carry out the analysis.

\section{Total content of flavonoids and phenolic acid}

Total contents of flavonoids (expressed as quercetin equivalents, \%) and phenolic acids (expressed as caffeic acid equivalents, \%) were determined spectrophotometrically, according to Polish Pharmacopoeia VIII [17]. The analyses were performed in triplicate.

\section{Total coumarins content and content of co- umarin}

Total content of coumarins was determined using spectrophotometric method [18]. For the analysis, $0.8 \mathrm{~g}$ of raw material was extracted in $100 \mathrm{ml}$ of chloroform for 4 hours in Soxhlet apparatus. The obtained extract was measured at a wavelength of $314 \mathrm{~nm}$. The results were calculated in \% DW.

The coumarin content was determined using HPLC-DAD analysis according to the methodology described by Bączek et al. [19]. The peak identification was confirmed by comparison of the retention time and UV-spectra with coumarin standard. The standard was purchased in ChromaDex (California, USA). Detection wavelength for coumarin was $276 \mathrm{~nm}$. The content of these compounds was calculated in mg per $100 \mathrm{~g}$ of DW. All the analyses were performed in triplicate.

\section{Statistical analysis}

The obtained results were subjected to statistical analysis using the Statgraphics Plus software (Statgraphics Technologies, Inc.). To determine the significance of differences between means the Tukey's test at a level of $p=0.05$, was applied. The data were expressed as mean values \pm standard deviation (SD) and the homogeneous groups were marked.

Ethical approval: The conducted rsearch is not related to either human or animal use. 


\section{RESULTS AND DISCUSSION}

Bastard balm is a typical undergrowth, shade-loving plant. Usually, it begins flowering in the second year of vegetation, however, the inflorescence shoots are weak, flabby and consist of only a few flowers [11]. In the third year of vegetation their productivity increases. According to this study, the development of both, generative and vegetative organs of bastard balm, is related not only to the age of plant but to the level of shade. In the experiment, the highest number of flowers, schizocarps, seeds per shoot and the highest 1000-seed mass was observed in the plants cultivated in moderate shade (fig. 1, 2). However, the viability of seeds collected from plants cultivated in full sunlight and those grown in moderate shade was estimated at a similar level (tab. 3 , fig. 3,4 ). The plants grown in full sunlight produced the highest number of shoots $\left(23.8 \mathrm{pcs} \times\right.$ plant $\left.^{-1}\right)$, although they were relatively short $(30.6 \mathrm{~cm})$, while those grown in deep shade produced the lowest number of shoots $\left(10.3\right.$ pcs $\times$ shoot $\left.^{-1}\right)$, but they were the longest ones $(43.1 \mathrm{~cm})$ (tab. 4). This tendency influenced the mass of herb, which was also modified by developmental stage of plants. The plants grown in full sunlight produced the highest mass of herb at the

Table 3

The influence of shade on generative traits.

\begin{tabular}{|c|c|c|c|c|}
\hline \multirow{2}{*}{ Traits } & \multirow{2}{*}{$\begin{array}{l}\text { Developmental } \\
\text { stage }\end{array}$} & \multicolumn{3}{|c|}{ Shade level } \\
\hline & & $0 \%$ & $30 \%$ & $50 \%$ \\
\hline Number of flowers per shoot & full flowering & $30.0 \pm 4.3 \mathrm{~B}$ & $41.60 \pm 5.4 \mathrm{~A}$ & $22.8 \pm 5.7 \mathrm{~B}$ \\
\hline Number of schizocarps per shoot & seed ripening & $9.0 \pm 1.9 \mathrm{~B}$ & $29.8 \pm 6.7 \mathrm{~A}$ & $13.8 \pm 3.6 \mathrm{~B}$ \\
\hline Number of mericarps per shoot & seed ripening & $18.2 \pm 4.1 \mathrm{~B}$ & $106.0 \pm 30.6 \mathrm{~A}$ & $14.60 \pm 6.1 \mathrm{~B}$ \\
\hline $\begin{array}{l}\text { 1000-seed mass } \\
(\mathrm{g})\end{array}$ & seed ripening & $17.56 \pm 0.53 \mathrm{~A}$ & $17.81 \pm 0.28 \mathrm{~A}$ & $16.27 \pm 0.28 \mathrm{~B}$ \\
\hline $\begin{array}{l}\text { Seed viability } \\
(\%)\end{array}$ & seed ripening & $80.0 \pm 0.75 \mathrm{~B}$ & $82.50 \pm 1.50 \mathrm{~A}$ & n.a. \\
\hline
\end{tabular}

Values are the mean $\pm S D$; values marked in rows with different letters differ at $p=0.05$.

Table 4

The influence of shade on yielding features

\begin{tabular}{|c|c|c|c|c|}
\hline \multirow{2}{*}{ Traits } & \multirow{2}{*}{ Developmental stage } & \multicolumn{3}{|c|}{ Shade level } \\
\hline & & $0 \%$ & $30 \%$ & $50 \%$ \\
\hline \multirow{5}{*}{$\begin{array}{l}\text { Number of shoots } \\
\text { per plant }\end{array}$} & 1 & $22.5 \pm 4.0 \mathrm{~b}$ & $17.4 \pm 3.6 \mathrm{~b}$ & $7.4 \pm 2.4 \mathrm{~b}$ \\
\hline & 2 & $30.2 \pm 5.1 \mathrm{a}$ & $22.0 \pm 3.4 \mathrm{a}$ & $8.0 \pm 2.9 \mathrm{~b}$ \\
\hline & 3 & $24.8 \pm 4.4 \mathrm{ab}$ & $25.1 \pm 4.2 \mathrm{a}$ & $12.0 \pm 4.2 \mathrm{a}$ \\
\hline & 4 & $17.8 \pm 4.0 \mathrm{c}$ & $22.8 \pm 3.1 \mathrm{a}$ & $13.6 \pm 3.1 \mathrm{a}$ \\
\hline & mean & $23.8 \mathrm{~A}$ & $21.8 \mathrm{~A}$ & $10.3 \mathrm{~B}$ \\
\hline \multirow{5}{*}{$\begin{array}{l}\text { Length of shoots } \\
{[\mathrm{cm}]}\end{array}$} & 1 & $31.1 \pm 2.6 \mathrm{a}$ & $35.2 \pm 3.3 \mathrm{~b}$ & $36.9 \pm 4.6 \mathrm{c}$ \\
\hline & 2 & $31.8 \pm 4.2 \mathrm{a}$ & $36.1 \pm 2.7 \mathrm{~b}$ & $39.0 \pm 5.8 \mathrm{c}$ \\
\hline & 3 & $30.4 \pm 3.4 \mathrm{ab}$ & $40.6 \pm 4.9 \mathrm{a}$ & $45.2 \pm 6.5 \mathrm{~b}$ \\
\hline & 4 & $28.9 \pm 3.3 \mathrm{~b}$ & $44.3 \pm 5.8 \mathrm{a}$ & $51.2 \pm 5.7 \mathrm{a}$ \\
\hline & mean & $30.6 \mathrm{~B}$ & 39.1AB & $43.1 \mathrm{~A}$ \\
\hline \multirow{5}{*}{$\begin{array}{l}\text { Fresh weight }(\mathrm{FW}) \\
\text { [g per plant] }\end{array}$} & 1 & $113.0 \pm 20.4 \mathrm{~b}$ & $110.1 \pm 14.0 \mathrm{c}$ & $58.2 \pm 12.0 \mathrm{~b}$ \\
\hline & 2 & $158.2 \pm 21.0 \mathrm{a}$ & $139.5 \pm 19.0 \mathrm{~b}$ & $77.5 \pm 12.5 b$ \\
\hline & 3 & $125.3 \pm 12.0 \mathrm{~b}$ & $198.0 \pm 22.5 \mathrm{a}$ & $124.1 \pm 19.6 \mathrm{a}$ \\
\hline & 4 & $52.7 \pm 10.7 \mathrm{c}$ & $143.6 \pm 15.6 \mathrm{~b}$ & $122.6 \pm 14.3 \mathrm{a}$ \\
\hline & mean & $112.3 \mathrm{AB}$ & $147.8 \mathrm{~A}$ & 95.6B \\
\hline
\end{tabular}

Developmental stage: 1 - beginning of vegetation; 2 - full flowering; 3 - beginning of seed-setting; 4 - end of vegetation Values are the mean $\pm \mathrm{SD}$; values marked in rows with different capital letters differ at $p=0.05$; values marked in columns with different small letters differ at $p=0.05$ 


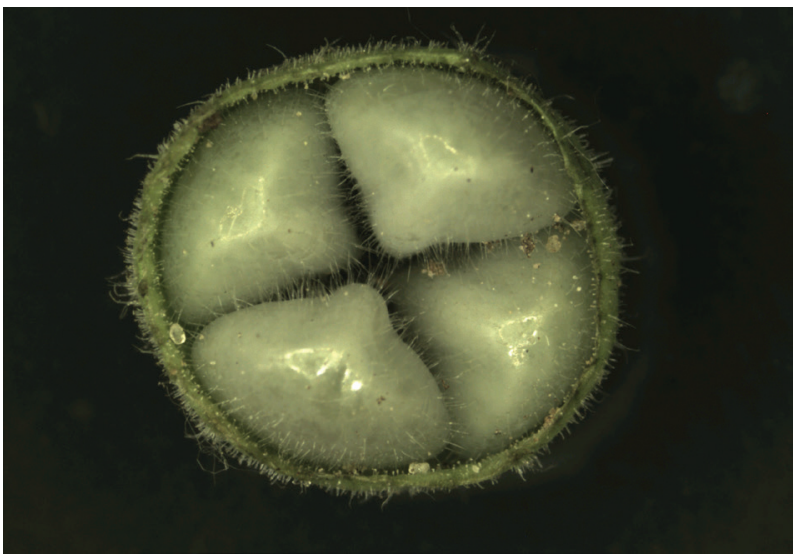

Figure 1

Melittis melissophyllum schizocarp

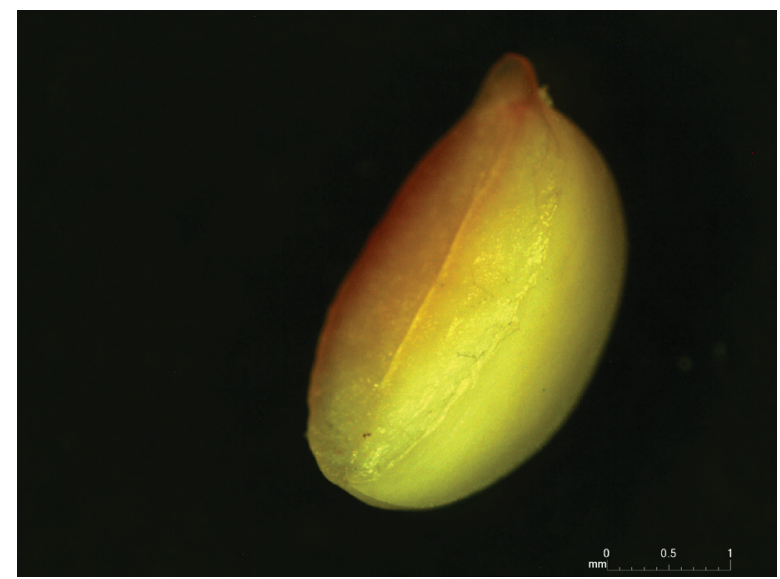

Figure 3

Non-viable seed

full flowering stage. For plants grown at a moderate and deep shade it was the highest at the beginning of the seed-setting stage. After the flowering period, the plants cultivated in full sunlight showed tendency to loose leaves and a part of their shoots withered. This was also visible for plants from moderate shade (tab. 4). Such phenomenon resulted in a significant decrease in the mass of herb of plants grown in full sunlight at the end of vegetation. In general, plants reveal a number of reactions to adapt to adverse environmental factors, including inappropriate radiation. Usually, changes in the morphological structure of leaves, their shape, size, thickness and content of chlorophyll are observed [20-23]. In this experiment, it was visible in the number and length of shoots. The plants grown in full sunlight produced short shoots with small, light-green leaves and those from deep shade formed long shoots with big, dark-green leaves (tab. 4). At a cellular level,

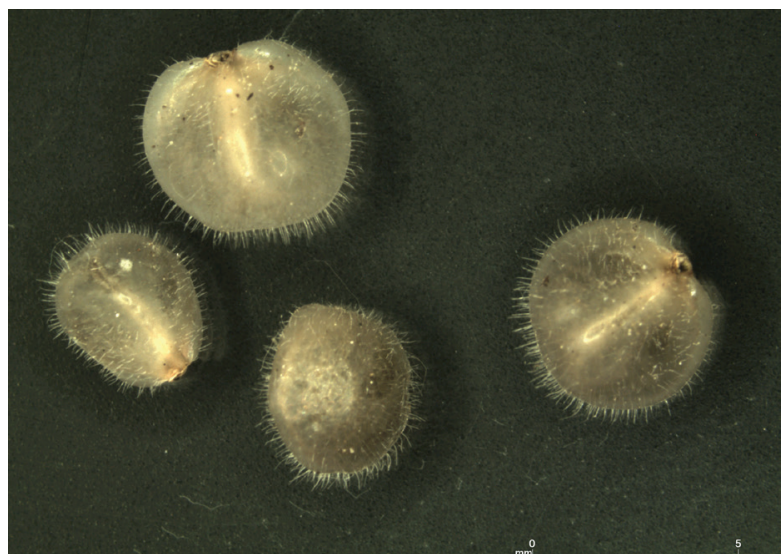

Figure 2

Melittis melissophyllum mericarps (commonly called seeds)

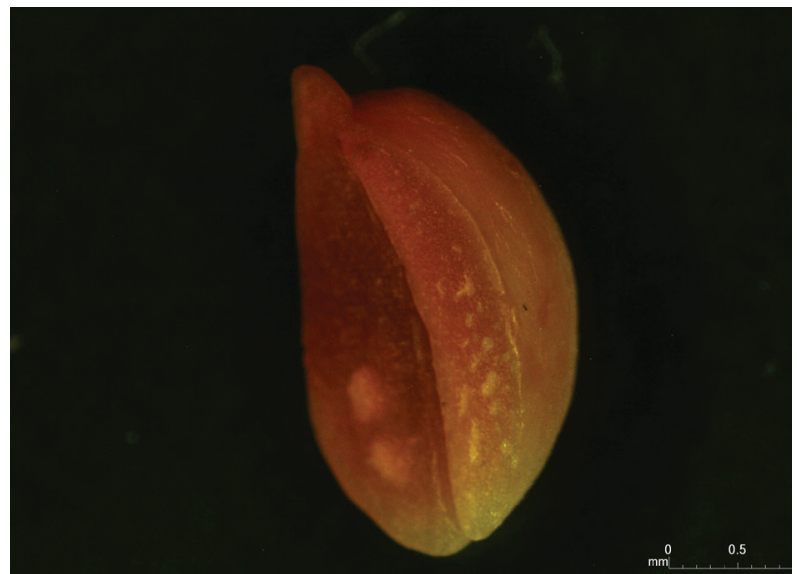

Figure 4

Viable seed

direct and high sunlight exposure may damage the photosynthetic system, especially in shade-loving plants. This is related with the overproduction of reactive oxygen species (ROS) induced by environmental stress. Usually, specific enzymes are utilized in scavenging and detoxification of ROS, including catalase, peroxidase or superoxide dismutase [2426]. Moreover, it was also reported that such conditions mobilize plants to synthesize biologically active compound, especially phenolics, as a specific 'secondary' antioxidant system [27, 28]. Intense production of flavonoids, induced by direct sunlight exposure was observed in our experiment, too. The total content of flavonoids was distinctly higher in plants cultivated in full sunlight in comparison to those from deep shade. High level of flavonoids in plants from full sunlight was seen especially during the flowering and at the beginning of seed-setting stage. Similar tendency was noted for total content 
of phenolic acids in plants from full sunlight and moderate shade. In the case of plants from deep shade the content of this compounds was the highest at the end of vegetation (tab. 5). Both flavonoids and phenolic acids regulate the development of specific plant organs and modulate its interactions with the environment $[27,28]$. Several authors report that specific phenolics affect the movement of auxin at both intra- and intercellular level. Usually, these compounds serve as protective substances synthesized to counter the stress-induced oxidative damage. They take part especially in response of plants to high radiation. Flavonoids have been described to accomplish their antioxidant role by preventing ROS production or/and by scavenging of ROS. They are accumulated in mesophyll, in the vacuole, chloroplasts or in the region of nucleus, protecting DNA from oxidation [24-28]. In this experiment, they were detected in higher quantities at the generative stage, which may confirm their protective role during this crucial phase, determining the possibility to obtain progeny plants. Higher content of some specific flavonoids and phenolic acids in plants grown at full sunlight compared to shaded ones was observed in previous research on bastard balm [5].

One of the most important groups of secondary metabolites in bastard balm herb are coumarins with coumarin used as a quality marker. This compound, next to essential oil, determines specific aroma of the raw material [7]. Although considered to induce liver toxicity, it is present in many plant products used on a daily basis, including cinnamon, tea, or lavender. In the previous investigation on bastard balm it was shown that the accumulation of coumarin in bastard balm herb may be related with light conditions during its growth [5]. It was confirmed in this study. The highest total content of coumarins and coumarin was observed in plants grown at deep shade; however, it was also related with the developmental stage of the plants. The content of coumarin in plants grown at deep shade had increased from the beginning of vegetation until the end of vegetation, whereas in full sunlight the highest content of this compound was observed at the

Table 5

The influence of shade on the accumulation of biologically active compounds

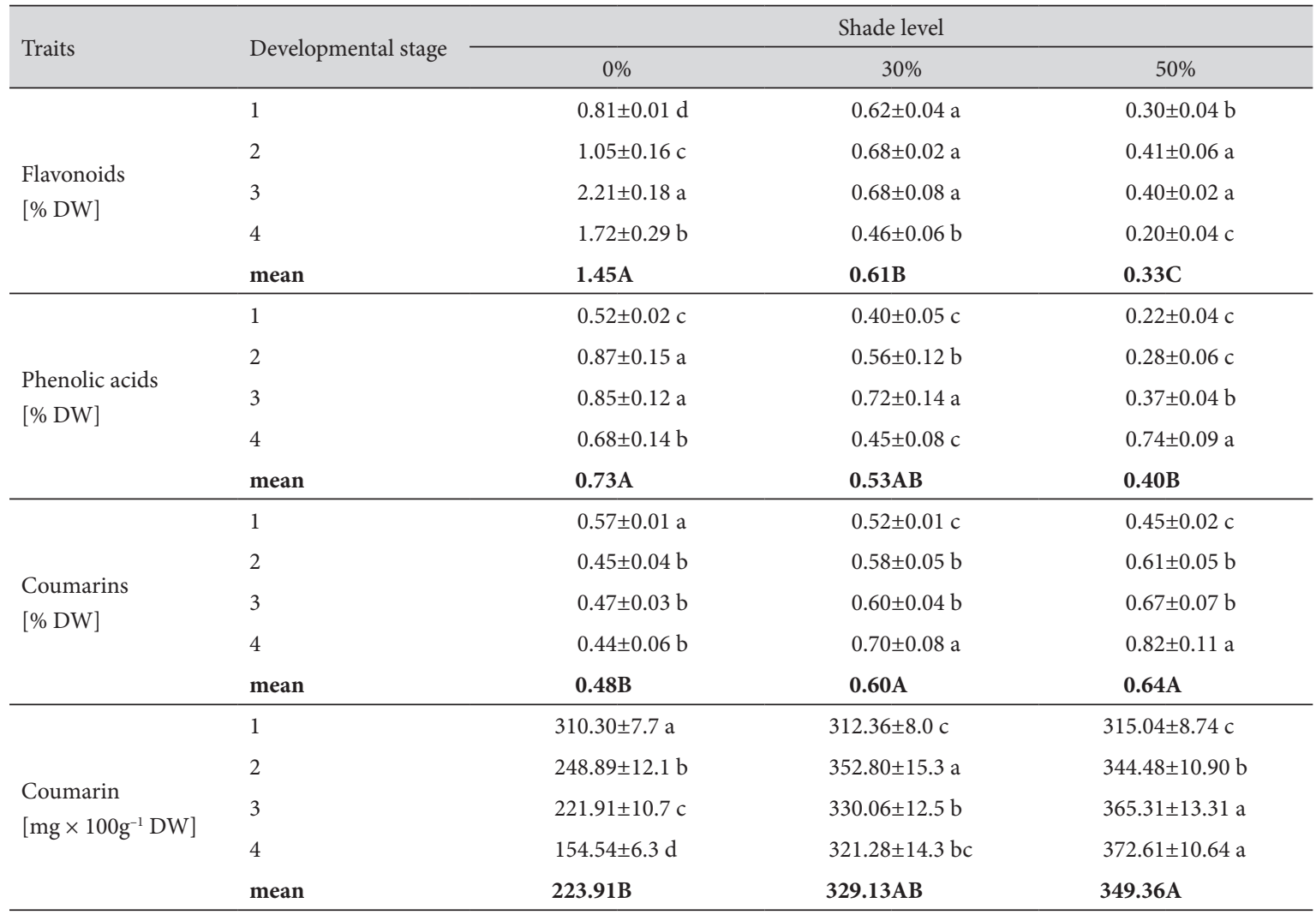

Developmental stage: 1 - beginning of vegetation; 2 - full flowering; 3 - beginning of seed-setting; 4 - end of vegetation; values are the mean $\pm \mathrm{SD}$; values marked in rows with different capital letters differ at $p=0.05$; values marked in columns with different small letters differ at $p=0.05$ 
beginning of vegetation, and then decreased (tab. 5). This relation was also observed in Hierochloë australis, where plants cultivated in deep (70\%) shade, compared to those grown in full sunlight or in $50 \%$ shade, synthesized the highest content of coumarin in leaves. However, it was combined with distinctly lower mass of raw material produced by the plant [29].

\section{CONCLUSIONS}

Under cultivation conditions, the reaction of plants to the limitation of sunlight access was expressed by both changes in their development and the accumulation of biologically active compounds in the herb. At 30\% shading, more dynamic plant development was observed and the plants were characterized by a clearly higher mass of herb and seeds. Shading distinctly increased the content of coumarin and decreased the content of flavonoids and phenolic acids in the raw material.

\section{Conflict of interest: Authors declare no conflict of} interest.

\section{REFERENCES}

1. Witkowska-Żuk L. Atlas roślinności lasów. Warszawa 2008:391-392.

2. Maggi F, Barboni L, Caprioli G, Papa F, Ricciutelli M, Sagratini G, et al. HPLC quantification of coumarin in bastard balm (Melittis melissophyllum L., Lamiaceae). Fitoterapia 2011; 82:1215-1221. doi: http://dx.doi.org/10.1515/hepo-2015-0023

3. Kaurinovic B, Popovic M, Vlaisavljevic S, Raseta M. Antioxidant activites of Melittis melissophyllum L. (Lamiaceae). Molecules 2011; 16:2152-3167. doi: http://dx.doi.org/10.3390/molecues16043152

4. Skrzypczak-Pietraszek E, Pietraszek J. Chemical profile and seasonal variation of phenolic acid content in bastard balm (Melittis melissophyllum L., Lamiaceae). J Pharmac Biomed 2012; 66:154-161. doi: http://dx.doi.org/10.1016/j.jpba.2012.03.037

5. Szymborska-Sandhu I, Przybył JL, Pióro-Jabrucka E, Jędrzejuk A, Węglarz Z, Bączek K. Effect of shading on development, yield quality of bastard balm herb (Melittis melissophyllum
L.). Molecules 2020; 25:2142. doi: http://dx.doi. org/10.3390/molecules25092142

6. Maggi F, Martonfi P, Conti F, Cristalli G, Papa F, Sagratini G, et al. Volatile components of whole and different plant parts of bastard balm (Melittis melissophyllum L., Lamiaceae) collected in Central Italy and Slovakia. Chem Biodivers 2011; 8:2057-2079. doi: http://dx.doi.org/ 10.1002/cbdv.201000365

7. Maggi F, Papa F, Cristalli G, Sagratini G, Vittori S. Characterization of the mushroom-like flavor of Melittis melissophyllum L. subsp. melissophyllum by headspace solid-phase microextraction (HS-SPME) coupled with gas chromatography (GC-FID) and gas chromatography-mass spectrometry (GC-MS). Food Chem 2010; 123(4):983-992. doi: http://dx.doi.org/10.1016/j. foodchem.2010.05.049

8. Łuczaj Ł. Wild food plants used in Poland from the mid- $19^{\text {th }}$ century to the present. Etnobiologia Polska 2011; 1:57-125.

9. Maggi F, Papa F, Cristalli G, Conti F, Sagratini $G$, Vittori S, et al. Histochemical localization of secretion and composition of the essential oil in Melittis melissophyllum L. subsp. melissophyllum from central Italy. Flavour Frag J 2009; 25:63-70. http://dx.doi.org/10.1002/ff. 1962

10. Grujić S, Stojanović G, Mitić V, Stankov-Jovanović V, Damić A, Alempić A, et al. Evaluation on antioxidant activity of Melittis melissophyllum L. extract. Arch Biol Sci 2014; 66(4):1401-1410. doi: http://dx.doi.org/10.2298/ABS1404401G

11. Rešetŭk OV, Terleckij BK, Filippenko AB. Features of the growth and cultivation of Melittiss sarmatica Klok. in Ukraine. University Novosibirsk 2013; C:336-338.

12. Kuhareva LV, Titok VV, Gil' TV. Biomorphological features of medicinal plants under conditions of introduction. Biological features of medicinal and aromatic plants and their role in medicine. International Scientific and Practical Conference, dedicated to the 85th anniversary of VILAR, 2016:102-105.

13. Załuski T, Paszek I, Gawenda-Kempczyńska D, Łazowy-Szczepanowska I. Preservation problem of heliophilous species in forest complex in Górzano-Lidzbark landscape park. Studia i Materiały 
CEPL w Rogowie 2015; 42:145-156.

14. Bączek K, Szymborska-Sandhu I, Pawełczak A, Węglarz Z. In vitro propagation of bastard balm (Melittis melissophyllum L.). Herba Pol 2015; 61(3):67-76. doi: http://dx.doi.org/10.1515/hepo2015-0023

15. World weather online. Warsaw Historical Weather. www.worldweatheronline.com. Access: 18.06.2020.

16. ISTA. International Seed Testing Association. Międzynarodowe Przepisy Oceny Nasiona. Polska Wersja Wydania, Radzików 2015; 6:3-8, 10:1-3.

17. Polish Pharmacopoeia VIII. Warszawa 2008; 150, 896.

18. Wierzchowska-Renke K, Stecka L. Oznaczenie zawartości kumaryn w żubrówce leśnej -Hierochloë australis (Schrad.) Roem. et Schult. Normae Herb 1976; 4:8-16.

19. Bączek K, Angielczyk M, Przybył JL, Kosakowska O, Ejdys M, Węglarz Z. Variability of southern sweet-grass (Hierochloë australis/Schrad./ Roem.\&Schult.) wild growing population occurring in eastern Poland. Herba Pol 2015; 61(3):2336. doi: http://dx.doi.org/10.1515/hepo-2015-0020

20. Anderson PC, Knox GW, Norcini JG. Light intensity influence growth and leaf physiology of Acuba japonica 'Variegata'. Hort Sci 1991; 26:14851488.

21. Cai ZQ, Chen YJ, Bongers F. Seasonal changes in photosynthesis and growth of Zizyphus attopensis seedlings in three contrasting microhabitats in a tropical seasonal rain forest. Tree Physiol 2007; 27:827-836. doi: http://dx.doi.org/10.1093/treephys/27.6.827

22. Van Hees AFM, Clerkx APPM. Shading and root-shoot relations in saplings of silver birch, pedunculated oak and beech. Ecol Manag 2003; 176:439-448. doi: http://dx.doi.org/10.1016/S03781127(02)00307-9
23. Hirano I, Iida H, Ito Y, Park H-D, Takahashi K. Effect of light condition on growth and defense compound contents of Datura inoxia and D. stramonium. J Plant Res 2019; 132:473-480. doi: http://dx.doi.org/10.1007/s10265-019-01111-z

24. Asada K. The water-water cycle in chloroplasts: Scavenging of active oxygens and dissipation of excess photons. Ann Rev Plant Physiol Plant Mol Biol 1999; 50:601-639. doi: http://dx.doi. org/10.1146/annurev.arplant.50.1.601

25. Cruz de Carvalho MH. Drought stress and reactive oxygen species. Plant Signal Behav 2008; 3:156165. doi: http://dx.doi.org/10.4161/psb.3.3.5536

26. Mittler R. Oxidative stress, antioxidants and stress tolerance. Trends Plant Sci 2002; 7:405-410. doi: http://dx.doi.org/10.1016/s1360-1385(02)02312-9

27. Karimi E, Jaafar HZE, Ghasemadeh A, Ibrahim $\mathrm{MH}$. Light intensity effects on production and antioxidant activity of flavonoids and phenolic compounds in leaves, stems and roots of three varieties of Labisia pumila Benth. Australian J Crop Sci 2013; 7:1016-1023.

28. Neugart S, Fiol M, Schreiner M, Rohn S, Zrenner R, Kroh LW, et al. Low and moderate photosynthetically active radiation affects the flavonol glycosides and hydroxycinnamic acid derivatives in kale (Brassica olreacea var. sabellica) dependent on two low temperatures. Plant Physiol Biochem 2013; 72:161-168. doi: http://dx.doi. org/10.1016/j.plaphy.2013.04.002

29. Podyma W, Bączek K, Angielczyk M, Przybył JL, Węglarz Z. The influence of shading on the yield and quality of southern sweet-grass (Hierochloë australis/Schrad./Roem.\&Schult.). Herba Pol 2010; 56(4):14-19. 